\title{
PENGARUH HUTANG JANGKA PENDEK DAN UKURAN PERUSAHAAN TERHADAP PROFITABILITAS PADA PT WIDJAYA DJAYA INDAH DI KOTA BATAM
}

\author{
Dian Efriyenty \\ Universitas Putera Batam \\ email : dianefriyenty@gmail.com
}

\begin{abstract}
This study aims to examine the effect of short-term debt and firm size on profitability at PT Widjaya Djaya Indah, located in Batam City. This research uses quantitative methods. The data collection technique in this study used a saturated sample technique, namely using the entire data obtained. The data analysis method used is descriptive analysis, classic assumption test which includes normality test, multicolonierity test, heterocedastity test and autocorrelation test, hypothesis test which includes $t$ test, f test, determination coefficient test and multiple linear regression. The sample used is 60 financial statement data from PT Widjaya Djaya Indah and the research objects used are the current ratio (X1), company size (X2), and return on assets $(Y)$. The data in this study were processed using SPSS version 21. The results of the $F$ test processing in this study indicate that simultaneously there is a positive and significant effect between the current ratio and company size on return on assets at PT Widjaya Djaya Indah. And the t test results show that the current ratio has a positive and significant effect on return on assets while company size has a negative and significant effect on return on assets.
\end{abstract}

Keywords: Current Ratio; Company Size; Return On Assets.

\section{PENDAHULUAN}

Pada umumnya, suatu perusahaan bersaing untuk dapat mempertahankan kelangsungan hidupnya dan mengembangkan usahanya dalam rangka mencapai tujuannya, yaitu menghasilkan laba yang semaksimal mungkin dari kegiatan bisnis yang dilakukan baik dalam bentuk barang maupun jasa. Untuk itu perusahaan dituntut untuk lebih mempersiapkan diri secara profesional sehingga perusahaan tidak hanya bisa bertahan dalam persaingan melainkan dapat berkembang dalam pasar modal. Perusahaan diharapkan memiliki keunggulan dalam pemasaran, sistem manajemen yang baik serta pengelolaan keuangan yang efektif dan efesien.

Sebelum melakukan proses menganalisis current ratio, perusahaan mestinya juga menganalisis seberapa besar atau kecilnya perusahaan tersebut, sehingga dapat membantu meminimaliskan tingkat resiko kerugian perusahaan. Oleh karena itu, dibutuhkan penelitian atas ukuran perusahaan, dimana penelitian ini diukur dengan total asset yang ada dalam perusahaan dan menggambarkan besar kecilnya perusahaan. Hal ini didukung oleh (Ananta, 2016 : 335) yang menyatakan ukuran perusahaan merupakan gambaran besar kecilnya asset yang dimiliki perusahaan.

Secara umum, kesuksesan suatu perusahaan dalam menjalankan aktivitasnya sering di dasarkan pada tingkat laba yang diperoleh. Akan tetapi laba yang besar belum tentu bisa mencerminkan atau menjadi sebuah ukuran bahwa perusahaan tersebut telah bekerja secara efesien. Tingkat efesiensi baru diketahui dengan cara membandingkan laba yang diperoleh dengan kekayaan atau modal yang menghasilkan laba tersebut. Rasio profitabilitas yang digunakan dalam penelitian ini adalah rasio Return On Assets (ROA).

PT Widjaya Djaya Indah merupakan perusahaan dagang yang bergerak di bidang supplier galangan kapal. PT Widjaya Djaya Indah memiliki berbagai saluran distribusi untuk 
memperdagangkan produknya. Banyaknya piutang yang tak tertagih mempengaruhi PT Widjaya Djaya Indah dalam pembayaran hutang kepada pemasok. Dimana hutang jangka pendek yang tertunggak oleh PT Widjaya Djaya Indah pada tahun 2016-2019 meningkat sebanyak 68\%. Semakin besar tingkat hutang memberikan dampak buruk kepada perusahaan sendiri atas kehilangannya mitra yang baik antara PT Widjaya Djaya Indah dan pemasok. Hal tersebut pada akhirnya mempengaruhi laba yang akan di peroleh.

Pada awal pendiriannya, PT Widjaya Djaya Indah memiliki ukuran perusahaan yang cukup besar dimana cukup untuk memperoleh laba yang maksimal dan menutupi hutang yang telah diambil, akan tetapi sejalan dengan perekonomian yang menurun, dari tahun ketahun asset yang dimiliki PT Widjaya Djaya Indah semakin sedikit. Dari segi asset yang dimilikinya sekarang, PT Widjaya Djaya Indah memiliki keterbatasan dalam memperoleh laba yang maksimal dan memiliki keterbatasan akses dalam mendapatkan sumber pendanaan dari luar.

Dari fenomena diatas dapat diketahui bahwa Profitabilitas yang semakin menurun dapat meningkatkan resiko kebangkrutan kepada PT Widjaya Djaya Indah. Naik atau turunnya profitabilitas PT Widjaya Djaya Indah sangat dipengaruhi oleh hutang jangka pendek dan ukuran perusahaan yang dimilikinya.

\section{Tabel 1 Return on Asset \\ PT Widjaya Djaya Indah \\ Periode 2016-2018}

\begin{tabular}{|c|c|c|c|c|}
\hline No & Tahun & Laba Bersih & Total Asset & ROA (\%) \\
\hline 1 & 2016 & $\operatorname{Rp~2.589.250.000}$ & $\operatorname{Rp~} 4.050 .390 .000$ & $63,92 \%$ \\
\hline 2 & 2017 & $\operatorname{Rp~2.125.400.000}$ & $\operatorname{Rp~3.822.412.000~}$ & $55,60 \%$ \\
\hline 3 & 2018 & $\operatorname{Rp~} 1.888 .970 .000$ & $\operatorname{Rp} 3.729 .012 .000$ & $50,65 \%$ \\
\hline
\end{tabular}

Sumber : Data sekunder

Pada tabel 1.1 dapat diketahui bahwa ROA (Return of asset) PT Widjaya Djaya Indah periode tahun 2016-2018 mengalami penurunan dari tahun ke tahun. Hal tersebut dapat disimpulkan bahwa adanya masalah dalam profitabilitas perusahaan yang timbul akibat banyaknya piutang yang tidak tertagih yang mengurangi keuntungan perusahaan, hutang jangka pendek yang tertunggak sehingga pemasok tidak mendukung perusahaan dalam pemberian kredit yang mengakibatkan kurangnya persediaan barang untuk dijual serta ukuran perusahaan yang semakin kecil yang tidak dapat memaksimalkan laba perusahaan.

Setelah mengetahui pentingnya hutang jangka pendek dan ukuran perusahaan terhadap return on asset maka perusahaan harus lebih teliti dalam mengatur pembayaran kepada pemasok untuk menghindari ketidaknyamanan dalam bekerja sama antara pihak pemasok dan perusahaan serta PT Widjaya Djaya Indah juga perlu mengolah asset yang ada secara maksimal untuk menghasilkan asset yang lebih besar sehingga dapat meningkatkan keuntungan perusahaan.

Kemudian menurut hasil penelitian (Kembau, 2016, : 374) menunjukkan bahwa hutang jangka pendek berpengaruh positif dan signifikan terhadap profitabilitas Sedangkan hasil peneliti (DJ, 2016: 111) menunjukkan bahwa ukuran perusahaan berpengaruh positif dan signifikan terhadap profitabilitas. Berdasarkan latar belakang masalah diatas dan melihat pentingnya pengaruh hutang jangka pendek dan ukuran perusahaan terhadap profitabilitas. 


\section{TINJAUAN PUSTAKA}

Hasil Pengembalian atas Aset (Return On Asset)

Menurut (Hery, 2016: 193) hasil pengembalian atas aset merupakan rasio yang menunjukkan seberapa besar kontribusi aset dalam menciptakan laba bersih. Dengan kata lain, rasio ini digunakan untuk mengukur seberapa besar jumlah laba bersih yang akan dihasilkan dari setiap rupiah dana yang tertanam dalam total aset. Rasio ini dihitung dengan membagi laba bersih terhadap total aset.

Berikut adalah rumus yang digunakan untuk menghitung hasil pengembalian atas aset:

$$
\text { Return On Assets }=\frac{\text { Laba Bersih }}{\text { Total Aset }} \text { Rumus 2.1 Return On Asset }
$$

Pengertian Hutang Jangka Pendek

Menurut (Syakur, 2016: 316) Hutang jangka pendek merupakan sumber pendanaan bagi kepentingan - kepentingan jangka pendek perusahaan. Oleh karena itu penyelesaian kewajiaban jangka pendek semestinya dilakukan dengan menggunakan aktiva lancar yang diperoleh dari kegiatan operasional atau dengan menimbulkan kewajiban jangka pendek baru.

\section{Rasio Lancar (Current Rasio)}

Rasio lancar adalah (Hery, 2016: 152) menggambarkan seberapa jumlah ketersediaan aset lancar yang dimiliki perusahaan dibandingkan dengan total kewajiban lancar. Oleh sebab itu, rasio lancar dihitung sebagai hasil bagi antara total aset lancar dengan total kewajiban lancar.

Berikut adalah rumus yang digunakan untuk menghitung rasio lancar:

$$
\text { Current Ratio }=\frac{\text { Current Assets }}{\text { Current Liabilities }} \text { Rumus 2.2 Current Ratio }
$$

\section{Ukuran Perusahaan}

Menurut (Pratama, I.G.B.A. \& Wiksuana, 2016: 1347) kecilnya ukuran perusahaan cukup mempengaruhi tingkat profitabilitas suatu perusahaan. Perusahaan yang berukuran lebih besar akan relative stabil dan mampu menghasilkan profit. Begitu pula sebaliknya, jika ukuran suatu perusahaan dikatakan kecil maka perusahaan tersebut memiliki tingkat efisiensi yang rendah. Investor dalam hal ini akan jauh lebih berhati-hati dan cenderung melakukan investasi saham pada perusahaan yang memiliki ukuran perusahaan yang besar karena memiliki tingkat resiko yang lebih kecil.

Menurut (Prasanjaya, A.A.Y. \& Ramantha, 2017: 235) rumus ukuran perusahaan adalah:

\section{Ukuran Perusahaan $=\operatorname{Ln}($ Total Aktiva)}

Rumus 2.3 Ukuran Perusahaan

\section{Penelitian Terdahulu}

Peneliti harus belajar dari peneliti lain, untuk menghindari duplikasi dan pengulangan penelitian atau kesalahan yang sama seperti yang dibuat oleh peneliti sebelumnya. Penelitian sebelumnya dipakai sebagai acuan dan referensi penulis dan memudahkan penulis dalam membuat penelitian ini.

(Elisa Purwitasari, 2017: 2) dalam jurnalnya yang berjudul Analisis Pengaruh Struktur Modal Terhadap Profitabilitas (Studi Empiris pada Perusahaan Manufaktur yang Terdaftar di BEI Tahun 2009-2011) berkesimpulan bahwa hutang jangka pendek berpengaruh negatif terhadap profitabilitas sedangkan hutang jangka panjang dan total hutang berpengaruh positif terhadap profitabilitas

(Meidiyustiani, 2017: 161) dalam jurnalnya yang berjudul Pengaruh Modal Kerja, Ukuran Perusahaan, Pertumbuhan Penjualan dan Likuiditas Terhadap Profitabilitas Pada 
Perusahaan Manufaktur Sektor Industri Barang Konsumsi Yang Terdaftar Bursa Efek Indonesia Pada Periode 2010 - 2014 berkesimpulan bahwa modal kerja, pertumbuhan penjualan dan ukuran perusahaan berpengaruh negatif terhadap profitabilitas, sedangkan likuiditas berpengaruh positif terhadap profitabilitas.

(Muhammad, Saminu Jibril, Wambai, Ibrahim, \& Ahmad, 2017) in his journal with tittle The Effect of Working Capital Management on Corporate Profitability: Evidence from Nigerian Food Product Firms conclude that inventory turnover, average payment have a negative impact to profitability and current ratio, firm size have positive impact to profitability.

Hipotesis

Berdasarkan konsep teori dan kerangka pemikiran diatas, maka hipotesis yang dikemukakan oleh penulis adalah sebagai berikut :

$\mathrm{H}_{1}$ : Current Ratio berpengaruh positif terhadap return on assets pada PT Widjaya Djaya Indah.

$\mathrm{H}_{2}$ : Ukuran Perusahaan berpengaruh positif terhadap return on assets pada PT Widjaya Djaya Indah.

$\mathrm{H}_{3}$ : Current ratio dan ukuran perusahaan secara simultan berpengaruh positif terhadap return on assets pada PT Widjaya Djaya Indah.

\section{METODE}

\section{Populasi dan Sampel}

Populasi yang digunakan dalam penelitian ini adalah perusahaan PT Widjaya Djaya Indah dengan data tahun 2015 sampai dengan 2019 atau selama lima tahun yang berjumlah 60 populasi. Teknik pengambilan sampel pada penelitian ini yaitu dengan sampel jenuh. Sampling Jenuh adalah teknik penentuan sampel bila semua anggota populasi digunakan sebagai sampel (Sugiyono, 2011: 68). Maka berdasarkan sampel perusahaan dalam total periode penelitian 5 (lima) tahun, jumlah sampel yang diperoleh adalah 60 sampel laporan keuangan.

\section{Teknik Pengumpulan Data}

Data kuantitatif yang digunakan dalam penelitian ini adalah laporan keuangan perusahaan PT Widjaya Djaya Indah yang diteliti dari tahun 2015 sampai dengan 2019. Teknik pengumpulan data yang digunakan berupa teknik dokumentasi. Teknik pengumpulan data yang digunakan berupa teknik dokumentasi dimana teknik pengumpulan data ini dilakukan dengan mencari data mengenai hal-hal atau variabel yang akan diteliti.

\section{Variabel Penelitian}

Definisi operasional variabel adalah penentuan variabel sehingga menjadi variabel yang dapat diukur. Variabel penelitian didalam penelitian ini terlihat sebagai berikut:

\section{Variabel Dependen}

ROA digunakan untuk mengukur seberapa besar jumlah laba bersih yang akan dihasilkan dari setiap rupiah dana yang tertanam dalam total aset (Hery, 2016: 193).

Berikut adalah rumus yang digunakan untuk menghitung hasil pengembalian atas aset:

$$
\text { Return On Assets }=\frac{\text { Laba Bersih }}{\text { Total Aset }} \text { Rumus 3.1 Return On Assets }
$$

\section{Variabel Independen}

1. $\quad$ Current Ratio $\left(\mathrm{X}_{1}\right)$

Rasio lancar adalah salah satu jenis rasio likuiditas yang digunakan untuk mengukur kemampuan perusahaan dalam memenuhi kewajiban jangka pendeknya yang segera jatuh tempo dengan menggunakan total aset lancar yang tersedia (Hery, 2016: 152). Berikut adalah rumus yang digunakan untuk menghitung rasio lancar: 


\section{Current Ratio $=\frac{\text { Current Assets }}{\text { Current Liabilities }}$ \\ Rumus 3.2 Current Ratio}

2. Ukuran Perusahaan $\left(\mathrm{X}_{2}\right)$

Menurut (Pratama, I.G.B.A. \& Wiksuana, 2016: 137) besar kecilnya ukuran perusahaan cukup mempengaruhi tingkat profitabilitas suatu perusahaan. Perusahaan yang berukuran lebih besar akan relative stabil dan mampu menghasilkan profit. Rumus untuk mencari ukuran perusahaan adalah:

\section{Ukuran Perusahaan $=\operatorname{Ln}($ Total Aktiva) Rumus 3.3 Ukuran Perusahaan}

\section{Analisis Data}

Metode analisis data yang digunakan dalam penelitian ini adalah : Analisis statistik deskriptif, Uji asumsi klasik (Uji normalitas, Uji multikolonieritas, Uji heteroskedastistas, dan Uji autokorelasi), Uji hipotesis (Uji t dan Uji f, Uji koefisioen determinasi, regresi linier ganda).

Analisis regresi berganda digunakan dalam penelitian ini untuk melihat pengaruh varabel independen terhadap variable dependen. Dengan demikian, variabel return on asset diterangkan oleh variable current ratio dan ukuran perusahaan. Sehingga bisa dirumuskan dengan persamaan berikut:

$$
\mathrm{Y}=\boldsymbol{\beta} 0+\boldsymbol{\beta} 1 \mathbf{X} 1+\boldsymbol{\beta} 2 \mathrm{X} 2+\mathrm{e}
$$

\section{Rumus 3. 4 Regresi Berganda}

Dimana :

$$
\begin{aligned}
& \text { Y : Return on asset } \\
& \text { X1 : Current Ratio } \\
& \text { X2 : Ukuran Perusahaan } \\
& \beta 0: \text { Konstanta } \\
& \beta 1 \beta 2 \beta 3: \text { Koefisien Regresi } \\
& \text { e }: \text { standard error }
\end{aligned}
$$

\section{HASIL DAN PEMBAHASAN}

\section{Isi Hasil dan Pembahasan}

Data yang digunakan dalam penelitian ini adalah data sekunder laporan neraca dan laporan laba rugi PT. Widjaya Djaya Indah dari tahun 2015 - 2019. Statistik deskriptif dilakukan dengan tujuan untuk mendeskripsi data atau membuat ringkasan data pada tahap pertama analisis data. Setelah data terkumpul, data diolah menggunakan IBM SPSS (Statistical Package For Social Science) Versi 24.

\section{Uji Asumsi Klasik}

\section{Uji Normalitas Data}

Untuk menguji normalitas data pada penelitian ini menggunakan uji Kolmogrov-Smirnov test. Dimana hasil pengujiannya menunjukkan data berdistribusi normal. Seperti yang ditunjukkan oleh tabel 2 dibawah ini: 
Tabel 2 Uji One-Sample Kolmogorov-Smirnov Test

One-Sample Kolmogorov-Smirnov Test

\begin{tabular}{|ll|r|}
\hline & & $\begin{array}{c}\text { Unstandardized } \\
\text { Predicted Value }\end{array}$ \\
\hline Normal Parameters ${ }^{\mathrm{a}}$ & Mean & 60 \\
& Std. Deviation & .0388333 \\
Most Extreme Differences & Absolute & .01519034 \\
& Positive & .073 \\
Kolmogorov-Smirnov Z & Negative & .056 \\
Asymp. Sig. (2-tailed) & & -.073 \\
a. Test distribution is Normal. & .564 \\
\end{tabular}

Sumber : Hasil Pengolahan SPSS 24

Hasil analisis metode One-Sample Kolmogorov-Smirnov Test, dapat dilihat bahwa nilai signifikan Asymp. Sig (2-tailed) senilai 0,909, maka dapat disimpulkan data memiliki distribusi normal karena kolmogorov-smirnov memiliki signifikansi 0,909 lebih besar dari 0,05.

\section{Uji Multikolinearitas}

Berdasarkan table output yang telah diolah oleh SPSS 24 yang melibatkan variable dependent maka dihasilkan table colinierity sebagai berikut:

Tabel 3 Uji Multikolinearitas

\begin{tabular}{|c|c|c|c|}
\hline & \multirow[b]{2}{*}{ Model } & \multicolumn{2}{|c|}{ Collinearity Statistics } \\
\hline & & Tolerance & VIF \\
\hline \multirow[t]{3}{*}{1} & (Constant) & & \\
\hline & CurrentRatio & .685 & 1.470 \\
\hline & UkuranPerusahaan & .610 & 1.639 \\
\hline
\end{tabular}

Sumber : Hasil Pengolahan SPSS 21

Berdasarkan hasil perhitungan terlihat bahwa VIF dari masing-masing variabel yaitu current ratio sebesar 1,470, dan ukuran perusahaan sebesar 1,639 dimaka kedua variabel tersebut masih kurang dari 10 . Dengan demikian dinyatakan model tidak memiliki hubungan multikolinearitas. 


\section{Uji Heterokedasitas}

Berikut adalah hasil dari uji heteroskedastisitas pada tabel 4 dibawah ini.

Tabel 4 Uji Heteroskedastisitas

\section{Coefficients $^{\mathrm{a}}$}

\begin{tabular}{|c|c|c|c|c|c|c|}
\hline \multirow{2}{*}{\multicolumn{2}{|c|}{ Model }} & \multicolumn{2}{|c|}{ Unstandardized Coefficients } & \multirow{2}{*}{$\begin{array}{c}\begin{array}{c}\text { Standardized } \\
\text { Coefficients }\end{array} \\
\text { Beta }\end{array}$} & \multirow[b]{2}{*}{$\mathrm{t}$} & \multirow[b]{2}{*}{ Sig. } \\
\hline & & B & Std. Error & & & \\
\hline \multirow[t]{3}{*}{1} & (Constant) & $4.198 \mathrm{E}-17$ & .063 & & .000 & 1.000 \\
\hline & CurrentRatio & .000 & .000 & .000 & .000 & 1.000 \\
\hline & UkuranPerusahaan & .000 & .003 & .000 & .000 & 1.000 \\
\hline
\end{tabular}

a. Dependent Variable: RES2

Sumber : Hasil Pengolahan SPSS 24

Suatu model dikatakan tidak mengalami gejala heteroskedastisitas jika nilai probabilitas atau signifikansi lebih dari 0,05. Berdasarkan tabel 4 di atas, dapat diketahui bahwa nilai probabilitas atau signifikansi untuk masing-masing variabel adalah sebesar 1,000. Maka dapat disimpulkan bahwa dalam model regresi tidak terdapat gejala heteroskedastisitas.

\section{Uji Autokorelasi}

Berikut merupakan hasil uji autokorelasi yang terlihat pada tabel 5 dibawah ini.

Tabel 5 Uji Autokorelasi

\begin{tabular}{|l|r|r|r|r|r|}
\hline Model & \multicolumn{1}{|c|}{$\mathrm{R}$} & R Square & \multicolumn{1}{c|}{$\begin{array}{c}\text { Adjusted R } \\
\text { Square }\end{array}$} & $\begin{array}{c}\text { Std. Error of the } \\
\text { Estimate }\end{array}$ & Durbin-Watson \\
\hline 1 & $.747^{\mathrm{a}}$ & .558 & .534 & .0138901 & 1.538 \\
\hline
\end{tabular}

b. Dependent Variable: ROA

Sumber : Hasil Pengolahan SPSS 24

Berdasarkan hasil Uji Autokorelasi diatas dapat dilihat bahwa nilai Durbin-Watson sebesar 1,538, nilai $\mathrm{dl}=1,480$ dan nilai $\mathrm{du}=1,689$, sehingga dapat disimpulkan bahwa $\mathrm{dl}<\mathrm{du}$ $<$ dw, maka berdasarkan tabel Durbin Watson dapat disimpulkan bahwa model regresi tersebut tidak mengalami autokorelasi.

\section{Hasil dan Pembahasan Uji Hipotesis}

Hasil pengujian hipotesis dari uji t, dan uji F dapat dilihat pada tabel dibawah ini:

1. Uji t

Berdasarkan hasil uji t dibawah bahwa semua hasil mengalami signifkansi yang lebih kecil dari 0,05 . 
Tabel 6 Hasil Uji t (Parsial)

\begin{tabular}{|c|c|c|c|c|c|c|}
\hline \multirow{2}{*}{\multicolumn{2}{|c|}{ Model }} & \multicolumn{2}{|c|}{ Unstandardized Coefficients } & \multirow{2}{*}{$\begin{array}{c}\text { Standardized } \\
\text { Coefficients } \\
\text { Beta }\end{array}$} & \multirow[b]{2}{*}{$\mathrm{T}$} & \multirow[b]{2}{*}{ Sig. } \\
\hline & & B & Std. Error & & & \\
\hline \multirow[t]{3}{*}{1} & (Constant) & .375 & .063 & & 5.980 & .000 \\
\hline & CurrentRatio & .001 & .000 & .631 & 5.876 & .000 \\
\hline & UkuranPerusahaan & -.016 & .003 & -.640 & -5.628 & .000 \\
\hline
\end{tabular}

a. Dependent Variable: ROA

Sumber : Hasil Pengolahan SPSS 24

\section{Uji F}

Pengujian ini dilakukan untuk mengetahui semua variabel independen $\left(\mathrm{X}_{1}, \mathrm{X}_{2}\right)$ yang dimasukkan dalam model memiliki pengaruh secara bersama-sama terhadap variabel dependen.

Tabel 7 Hasil Uji F (Simultan)

\begin{tabular}{|ll|r|r|r|r|r|}
\hline \multicolumn{1}{|c|}{ ANOVA $^{\mathbf{b}}$} & & \\
\hline 1 & Sum of Squares & Df & Mean Square & F & Sig. \\
\hline & Regression & .014 & 2 & .005 & 23.521 & $.000^{\mathrm{a}}$ \\
& Residual & .011 & 56 & .000 & & \\
Total & .024 & 59 & & & \\
\hline
\end{tabular}

a. Predictors: (Constant), UkuranPerusahaan, CurrentRatio

b. Dependent Variable: ROA

Sumber : Hasil Pengolahan SPSS 24

Hal ini dapat dibuktikan dari nilai $F_{\text {hitung }}$ sebesar 23,521 $>F_{\text {tabel }}$ sebesar 2,77 serta taraf signifikan sebesar $0,000<0,05$, maka dapat disimpulkan $\mathrm{H}_{\mathrm{a}}$ diterima dan $\mathrm{H}_{0}$ ditolak, yang menunjukkan current ratio dan ukuran perusahaan berpengaruh secara simultan terhadap ROA.

Berdasarkan hasil uji t dan uji f pembahasannya adalah sebagai berikut:

Pengaruh Current Ratio Terhadap Profitabilitas (Return On Asset)

Berdasarkan hasil uji t, variabel current ratio mempunyai nilai signifikan 0,000 yang berarti nilai ini lebih kecil dari 0,005 dan t-hitung yang diperoleh 5,876 > t-tabel 2,00324. Maka dapat disimpulkan bahwa $\mathrm{H}_{1}$ diterima yang berarti bahwa, current ratio berpengaruh positif terhadap profitabilitas (Return On Asset).

Hasil penelitian ini sesuai dengan hasil penelitian (Kembau, 2016) yang menyatakan bahwa current ratio berpengaruh positif terhadap Return On Assets. Adanya pengaruh positif berarti bahwa aktiva lancar yang dimiliki perusahaan lebih besar daripada hutang lancarnya, sehingga memungkinkan perusahaan untuk melunasi hutang lancarnya pada saat jatuh tempo. Pada sisi lain, rasio lancar yang tinggi juga menyatakan bahwa terjadi kurang efektifnya manajemen kas dan persediaan. 
Pengaruh Ukuran Perusahaan Terhadap Profitabilitas (Return On Asset)

Berdasarkan hasil uji t, variabel ukuran perusahaan mempunyai nilai signifikan 0,020 yang berarti nilai ini lebih kecil dari 0,005 dan t-hitung yang diperoleh -5,628 < t-tabel 2,00324. Maka dapat disimpulkan bahwa $\mathrm{H}_{2}$ diterima yang berarti bahwa ukuran perusahaan terhadap Return On Assets.

Hasil penelitian ini sesuai dengan hasil penelitian (Kembau, 2016) yang menyatakan bahwa ukuran perusahaan berpengaruh negatif dan signifikan terhadap Return On Assets. Secara teori ukuran suatu perusahaan salah satunya dapat dilihat dari aktiva yang dimiliki perusahaan, karena aktiva menggambarkan tersedianya sumber daya untuk kegiatan perusahaan dimana kegiatan tersebut cenderung dilakukan untuk memperoleh laba. Dalam hasil penelitian ini menyatakan bahwa ukuran perusahaan berpengaruh negatif terhadap Return On Assets. Kondisi ini bisa terjadi karena aktiva yang besar belum tentu bisa meningkatkan profitabilitas perusahaan. Hal ini juga membuktikan total aset yang besar bukan merupakan jaminan perusahaan memiliki kinerja yang baik. Jika total asset yang besar tersebut tidak mampu dikelola dan dimanfaatkan secara maksimal oleh perusahaan, yang mana artinya kinerja perusahaan tidak efisien, sehingga tidak mampu menghasilkan laba yang optimal.

Pengaruh Current Ratio dan Ukuran Perusahaan terhadap Profitabilitas (Return On Asset)

Hutang adalah kewajiban keuangan perusahaan kepada pihak lain yang belum terpenuhi, dimana hutang ini merupakan sumber dana perusahaan yang berasal dari kreditor Apabila pinjaman atau hutang (hutang jangka pendek) mengalami perubahan maka profitabilitas suatu perusahaan juga akan mengalami perubahan. Naiknya hutang akan menaikkan profitabilitas dan sebaliknya turunnya hutang juga menurunkan profitabilitas. Pada saat kondisi ekonomi baik, suku bunga pinjaman umumnya rendah dan penjualan serta laba perusahaan meningkat. Kemampuan perusahaan untuk menghasilkan laba dengan menggunakan hutang lebih besar daripada tingkat bunga yang harus ditanggung perusahaan. Namun, penggunaan hutang jangka pendek memiliki risiko. Jika perusahaan tidak mampu mempertahankan kemampuan membayar hutang jangka pendek maka pada umumnya perusahaan tersebut tidak akan mampu membayar hutang jangka panjang dan tidak akan mampu memuaskan pemegang saham.

Ukuran perusahaan yang lebih besar memiliki akses yang lebih besar untuk mendapat sumber pendanaan dari berbagai sumber sehingga memperoleh pinjaman dari kreditur pun akan lebih mudah karena perusahaan dengan ukuran besar memiliki profitabilitas lebih besar untuk memenangkan persaingan atau bertahan dalam industri. Semakin besar ukuran suatu perusahaan, maka kecenderungan menggunakan modal asing juga semakin besar. Hal tersebut dikarenakan perusahaan besar membutuhkan dana yang tidak kecil untuk menunjang operasionalnya, dan salah satu cara pemenuhannya adalah dengan modal asing apabila modal sendiri tidak mencukupi.

\section{SIMPULAN}

Berdasarkan hasil penelitian dan pembahasan yang telah diuraikan, maka penulis menarik kesimpulan adalah sebagai berikut:

1. Variabel current ratio $\left(\mathrm{X}_{1}\right)$, secara parsial berpengaruh positif dan signifikan terhadap profitabilitas (Return On Assets), dimana t-hitung yang diperoleh 5,876 > t-tabel 2,00324, dan nilai signifikan 0,000 lebih kecil dari 0,005, sehingga dapat disimpulkan hipotesis kedua diterima.

2. Variabel ukuran perusahaan $\left(\mathrm{X}_{2}\right)$, secara parsial berpengaruh negatif dan signifikan terhadap profitabilitas (Return On Assets), dimana t-hitung yang diperoleh -5,628< ttabel 2,00324, dan nilai signifikan 0,000 lebih kecil dari 0,005, sehingga dapat disimpulkan hipotesis ketiga diterima.

3. Hasil penelitian ini menunjukkan bahwa current ratio dan ukuran perusahaan secara simultan berpengaruh terhadap (Return On Assets) dengan nilai $\mathrm{F}_{\text {hitung }}$ sebesar 23,521 > 
4. $F_{\text {tabel }}$ sebesar 2,77, dan nilai signifikan sebesar $0,000<0,05$, sehingga hipotesis keempat diterima profitabilitas.

\section{SARAN}

Berdasarkan hasil penelitian penulis mengusulkan saran-saran yang kiranya bermanfaat bagi pihak-pihak yang terkait dalam penelitian yaitu :

1. Bagi Perusahaan dan Investor

Bagi perusahaan diharapkan untuk lebih memerhatikan manajemen kas dan persediaan untuk meningkatkan profitabilitas yang maksimal. Bagi investor disarankan untuk memperhatikan tingkat Return On Assets (ROA), karena ROA menunjukkan besarnya laba yang akan diperoleh dari investasi yang telah ditanamkan oleh investor.

1. Bagi Penulis

Penelitian yang telah dilakukan memiliki kekurangan dan keterbatasan sehingga masih perlu mendapatkan perbaikan karena keterbatasan variabel yang diteliti hanya meliputi current ratio, ukuran perusahaan, dan profitabilitas (Return On Assets) sehingga bagi pihak yang memanfaatkan hasil penelitian dapat mengetahui kekuranga dan kelemahan penelitian untuk dapat diantisipasikan.

2. Bagi Akademis

Bagi peneliti selanjutnya disarankan untuk menambahkan atau menukar variabel independen lainnya dan populasi pada sektor lainnya yang dapat mempengaruhi profitabilitas.

\section{DAFTAR PUSTAKA}

Ananta, dkk. (2016). Pengaruh Ukuran Perusahaan, Kecukupan Modal, Kualitas Aktiva Produktif dan Likuiditas terhadap Kinerja Keuangan Perbankan Umum Syariah Periode 2011-2014. Jurnal Prosiding Akuntansi, (ISSN: 2460-6561).

Elisa Purwitasari, A. S. (2017). Analisis Pengaruh Struktur Modal Terhadap Profitabilitas (Studi Empiris Pada Perusahaan Manufaktur Yang Terdaftar di BEI Tahun 2009-2011). Diponegoro Journal Of Accounting, 2 No 3(2337-3806), 1-11.

Hery. (2016). Analisis Laporan Keuangan. Jakarta: PT Grasindo.

Kasmir. (2016). Analisis Laporan Keuangan. Jakarta: PT Raja Grafindo Persada.

Kembau, R. P. H. (2016). Rasio, Pengaruh Dan, Hutang Kredit, Rasio Profitabilitas, Terhadap Terdaftar, Yang Idx, D I Ekonomi, Fakultas Bisnis, Dan Akuntansi, Jurusan, 2(4), 374385.

Meidiyustiani, R. (2017). Pengaruh Modal Kerja, Ukuran Perusahaan, Pertumbuhan Pejualan dan Likuiditas Terhadap Profitabilitas Pada Perusahaan Manufaktur Sektor Industri Barang Konsumsi Yang Terdaftar Di Bursa Efek Indonesia (BEI) Periode Tahun 20102014, 5 No 2(ISSN 2252 -7141), 183-199.

Muhammad, S., Saminu Jibril, R., Wambai, U. S. K., Ibrahim, F. B., \& Ahmad, T. H. (2017). The Effect of Working Capital Management on Corporate Profitability: Evidence from Nigerian Food Product Firms. Applied Finance and Accounting, 1(2), 55-63. https://doi.org/10.11114/afa.v1i2.842

Prasanjaya, A.A.Y. \& Ramantha, I. W. (2017). Analisis Pengaruh Rasio CAR, BOPO, LDR, dan Ukuran Perusahaan Terhadap Profitabilitas Bank Yang Terdaftar Di BEI. E-Jurnal Akuntansi Universitas Udayana, (ISSN: 2302-8556).

Pratama, I.G.B.A. \& Wiksuana, I. G. . (2016). Pengaruh Ukuran Perusahaan dan Leverage Terhadap Nilai Perusahaan Dengan Profitabilitas Sebagai Variabel Mediasi. E-Jurnal Manajemen Unud, (ISSN: 2302-8912).

Syakur, A. S. (2016). Intermediate Accounting. Jakarta: Pembuka Cakrawala. 